\title{
CHALLENGES FOR EDUCATION CAREER IN THE LITHUANIAN SCHOOLS OF GENERAL EDUCATION: EXPERIENCE OF CAREER SPECIALISTS
}

\author{
Odeta Merfeldaite \\ Mykolas Romeris University, Lithuania \\ Asta Railiene \\ Mykolas Romeris University, Lithuania \\ Valdone Indrasiene \\ Mykolas Romeris University, Lithuania \\ Violeta Jegeleviciene \\ Mykolas Romeris University, Lithuania
}

\begin{abstract}
The article presents the challenges for the career specialist in provision of career education services in the school of general education. Based on the results of the qualitative research, employing the methods of the focus group discussion, the following conclusions should be made: The main problems faced by the career specialists providing career services in general education schools are the following: heavy workload, lack of cooperation among the career specialists; the schools lack informational and methodological means which would correspond to special needs of the students, of age groups; for improvement of efficiency of the activity of career specialists an information data base containing all available informational, counselling, methodological material designated for the career specialist is required; psychological tests on the subjects of self-awareness and career which could be applied by career specialists on their own, without having psychological education; lack of attractive, corresponding to the needs of the modern labour market and of the students, video material designated for career education; training based on sharing of experience is necessary for qualification improvement
\end{abstract}

Keywords: career specialist, career education, career services, general education school.

\section{Introduction}

The modern concept of a career, permanently changing situation of economy and on the labour market encourage actualization of the career education services in schools. If earlier, for the purpose of career education, the ability of a pupil to answer the question "what will be your profession when you grow up" was indicated, today the development of career competences which enable a student to know, to create and to self-realise oneself in the permanently changing world 
Merfeldaite et al., 2020. Challenges for Education Career in the Lithuanian Schools of General Education: Experience of Career Specialists

becomes the main purpose of career education at school. The competences which enable the person himself to control one's career are the essential ones in the modern world with changeable labour market. (Career Guidance: A Handbook for Policy Makers, 2004). The importance of development of career competences in career education is actualised in the national documents (Law on Education, 1991, 2011,2017; the Strategy on Lithuanian Progress "Lithuania 2030"; the National Strategy for Education 2013-2022; Program for Career Education, 2014), where the necessity to provide favourable conditions for individuals to independently control their careers, also to provide individualised assistance in real and virtual environment for the individuals who seek to develop the key competences, forming conscious selection of one's way of life (career), as well as continuity of development, are emphasized.

Longitudinal researches (Hughes et al., 2016) show that the way the teenagers think about the prospective of their learning and occupation has serious influence on their becoming as grown-up employees. Statistically it is more probable that the teenagers who did not assess efficiently the education, which is necessary for their targeted position on the labour market, in future more often are within the youth group NEET (Not in Education, Employment or Training). It has been established, that young people coming from poorer families tend more to have career ambitions which are non-compliant with their studying ambitions. Thus, preparation of young individuals to make adequate, qualitative career decisions is one of the essential tasks in the career education. Career education shall become a part of the complex career support available for each young individual. The results of Nusche (2008) research prove that purposeful, consistent career education is an essential presumption which ensures the quality of transition of the young people from school to other environments of the world of learning, studies and work. It should be noted that the researches of the recent decade disclose that pupils in the last school years very often are still undecided about their career aspirations (Rogers \& Creed, 2000; Ramanauskaite et al., 2004; Pukelis, 2012; Kalinauskaite et al., 2005; Garnienè, 2006; Ustinavičiūtè et al., 2011; Meijers et al., 2012), their career expectations are limited to the wish for university studies or getting a well-paid job (Sinclair et al., 2014; Schuette et al., 2012; Thompson \& Dahlin, 2010; Kattenbac et al., 2010; Howard et al., 2011). The decision-making for a pupil is impeded by fragmentary nature of career education, career information and career counselling services at school. Career services often are provided chaotically and in fragments, there is a lack of a system for preparation and activity of career specialists (Pukelis \& Katsarov, 2014). Though the preparation of the first career specialists (vocational counsellors) was started already in 2003, but the existing preparation of career specialists is based on the initiative of individual institutions of higher education (Railiene, 2007; Navickiené, 2012). During the past five years no national researches were made 
on comprehensive analysis of the challenges for the career specialists in provision of career education services in the school of general education.

The problem of the research is formulated by the questions: what problems do the career specialists face while providing the career education services?

The subject of the research is the experience of the career specialist.

The purpose of the research is to disclose the challenges in the career specialist's activity providing the career education services in the school of general education.

The methods of the research: analysis of scientific literature and qualitative research employing the method of the focus-group. The data of the research have been analysed using the method of content analysis.

\section{Research methodology}

A qualitative research has been performed employing the method of focus group discussion. The focus group method is especially fit for discussion of different experiences, generation of new ideas, specifying the existing beliefs, disclosing the causes of conduct, foreseeing the potentials of improvement of a situation, obtaining more thoughtful interpretations of the case at issue (Denzin \& Lincoln, 1994; Patton, 2005; Flick, 2014). The research was performed in 2018, under the order of the Lithuanian Education Exchanges Support Foundation. Only a part of the results of the research - those associated with the challenges to career specialists of general education schools in provision of services for career education - was used in the article thereof.

The members for the focus group were selected by a common feature - career specialists working at schools of general education. This allowed ensuring that all members of the focus group have similar interests and experiences. The focus groups were constructed based on the principle of homogeneity in the context of social characteristics: education (with or without the education associated with provision of carrier services), work experience (work experience in the sphere of career services from 0.5 year to 17 years), regions (work at schools of general education in different regions), types of schools (pre-gymnasium, lower secondary education school, gymnasium).

Two discussions of the focus groups were held, with the following participants: Group 1: the experienced career specialists (employed as career specialists or performing the function of a career specialist for more than 3 years); Group 2: the freshmen career specialists (employed as career specialists or performing the function of a career specialist for less than 3 years). The selected size of a focus group - 10 investigative participants.

The participants in the discussion were in advance informed about the goal of the research. Duration of one session was approximately 1.5 - 2 hours. All 
Merfeldaite et al., 2020. Challenges for Education Career in the Lithuanian Schools of General Education: Experience of Career Specialists

members of the focus groups participated voluntarily. Written consents for participation in the discussion of the focus group were obtained from all informants, as well as consents regarding the data fixation and recording by dictaphone. The informants were notified of the goal and the objectives of the research, informed about the use of the research data, the potential risks and the right to withdraw from the research. The principle of confidentiality was observed during the entire performance of the research: nobody but the team of the researchers may use the information provided by the informant without his/her consent; the information presented in the report is impersonal - the names of the informants were replaced with codes. Great attention was paid to the principle of respect of the privacy of the individual: the researchers tried to disturb the participants of the research as little as possible and be impartial towards the ideas presented by them. The principle of goodwill and disposition to not harm the individual is based on the researchers' respect of personal privacy: in the report on the research the aspects which are sensitive for the participants are presented correctly.

Qualitative content analysis was selected for the data analysis - a creative process of thinking with the purpose of decoding the meanings contained in the text, to realise and to identify the challenges arising in front of the career specialists in the context of provision of services in the career education. In the first step highlighting, based on the theoretical material, of semantic units (elements) was made. In the second step the semantic units were joined/ grouped into sub-categories, presenting significant propositions. In the third step the categories were formed. After performance of the above-mentioned steps, in order to secure reliability of the data, it was revised repeatedly.

\section{Results of the research: findings}

The outgivings of the focus groups allowed distinguishing three categories: activity organization, needs and variety of informational and methodological means, and (self-) improvement of qualification. The category Activity Organization is specified by four sub-categories: heavy workload, the procedure for work payment, absence of full-time or part-time posts and cooperation.

According to the participants of the research, the most sensitive issues are associated with the organisation of their activity in the school of general education. The informants note heavy workload ("There are many pupils in our school - 1400. I can say that I work alone with the career issue. Sometimes somebody stands by, or not, but I definitely do not feel much support. $<\ldots>$ After that I realised that I am not able to run this alone $<\ldots$... " (L1); " $<$ I have two hands, and a lot of functions" (R1)). The informants distinguish underpayment for their work as one of the most problematic aspects of the organisation of career 
specialists' activity: “<...in general, factually people who do this work, work just for the idea. Because, just give the person the work and give no money, and you will see who withdraws and who does not." (E V1); "Of course, with some payment maybe there would be some more interested people, this would mean some motivation. Because now people are driven just by some inner wish."(D2).

It has been disclosed that, when speaking about the challenge of cooperation in provision of the career education services, the specialists, first of all, note the importance of involvement of the entire school community into provision of career services (" $<\ldots>$ for efficient career education at school, more teachers have to be involved <...> ". I do not believe that this should be a one-person initiative, as the experience shows that when more teachers are involved into this, the children feel that." (A2); "<..> anyway, the entire school has to cooperate." (A2); "we need assistance from the class misters, as we are just trying."(J 2)). It should be noted that this particular challenge is indicated only by the freshmen career specialists. This allows making the assumption about the relevance of improvement of managerial-organisational competences for freshmen career specialists.

The career specialists noted also the lack of inter-cooperation: "You are sitting, leading a seminar and say - share one method each, so we are twenty participating, how nice. Just say one, maybe its familiar, but it might be a reminder. Nobody said about their methods. Should it be buried then? $<\ldots>$ the culture of sharing is needed" (GV1); "But I understand that we are not sharing, that one does not know what the others are breathing. I know what the school is breathing, but not about the others." (EM 1).

The participants of the research emphasize the problem of the full-time or part-time career specialist staff. Career services in some schools of general education are provided by career specialists having a part-time post; in the other schools the function is attributed and/or integrated into the work hours of teachers or of assisting specialists. It has been disclosed that the major challenges arise for those career specialists who have the activity of the career function attributed to them, as to the assisting specialists (psychologists, social pedagogues). This function is attributed to the assisting specialists in relation to the duty functions performed by them ("<...> I face the career education as a social pedagogue, as a specialist. There is no full-time establishment, as the directors says to me and to my colleague that this is within the duties" (V1); "Me, as a psychologist, have the function to advise the children on selection of a profession, on the direction, so this is as if additional functions and in the school I am a chairperson of the coordination group of career education" $\left(\mathrm{O}_{2}\right)$ ). It should be noted that the additional payment for social pedagogues, psychologists for the functions performed depends on the goodwill of the administration. In some schools they are paid by adding 5 per cent bonus to their salary (by September 2018), a part of 
Merfeldaite et al., 2020. Challenges for Education Career in the Lithuanian Schools of General Education: Experience of Career Specialists

the establishment for additional activities $(<\ldots>$ so the director used to pay me 0.25 extra for a huge amount of activities performed. It was not limited just to what was within the function, she really was well-wishing in this sense." (L 1)). But in many cases the support specialists providing career services are not paid extra. The participants of the research noted that the function of service provision is attributed also to the teachers of subjects, by adding additional hours for informal education (" $<\ldots>$ it was allocated from the informal education, I had 2 hours there and plus 1 hour, the same activity, only that it was of project-type. So, as if we have 3 hours" (E 1); "<... I have 1 hour of informal education so that there would be a possibility to pay. $<\ldots>$ in normal times that meant a half of an academic hour per week $<\ldots>$ ".. (G 1); “<... I work as a teacher of German and English, and the career counselling is just assigned to me as the additional hours" (J 2)).

The second semantic category defining the challenges in the activity of career specialists should be related to the lack of informational and methodological means and their diversity. This category is specified with three sub-categories: the response to the needs of the pupils; the purpose of the means; the form of the means. Speaking about the problem of differentiation according to the needs of the pupils the participants of the research note the lack of the means designated for the work with large groups of pupils: " $<\ldots$.. the game "Labyrinth of Professions", OK, you can play it in a small group, and when you have 30 in the class-room, ant it takes usually more than 45 min." ( $G V 1)$. It has been disclosed by the research that there is a special lack of informational and methodological means for the pupils with special needs of education. ("Now we have two classes with pupils with serious special needs and serious intellect disorders. $<\ldots>$ there is always a challenge where to guide them after graduation, in helping the parents to find their places. And if such child has possibilities to study further somewhere, to get some profession <...>." (D 2); "Factually, the means, information for those children [with special needs] do not exist at all. You yourself have find ways out, do something, find out, make phone calls, inquire who could accept, what the conditions are. So it would be very nice if the means for such children would be simple, as, definitely, not all children with serious intellect disorders are able to watch sort of films, as not all of them would understand what is shown." (D 2)).

Vrasmas, Vrasmas (2012) note that for the pupils with special education needs the transition from school to work is a complicated process because of several difficulties - the negative attitude of other people towards disability and because of the complexity of services.

The participants of the research also note the lack of measures concerning the knowledge of career possibilities and the competences for integration on the labour market: "Something about possibilities of studies, then employment 
simulation <...> ( $G \vee V 1)$; "There is the lack of methodological means for counselling of pupils on the subjects of the situation on the labour market, on the demand for professions <...> methodological means, labour market, how to look for a job. Most often it is the most difficult to find means on those subjects for pupils. $<\ldots>$ We would like more information means $<\ldots>$ methodological means, tasks about the trends on the labour market, about the specialists, the professions to be demanded in the future. On efficient search for a job." (E P 2).

The participants of the research emphasize also the lack of informational, consultancy means on the subject of self-awareness: " $<\ldots>$ so that the selfawareness would be different, how to accumulate the information of the surrounding people about oneself, the values, own talents, own informal life. Isn't that so? So you could see <...>." (G V 1); "we miss standardised and adapted education means for self-awareness" ( $L$ 2); "There is the lack also of methodological means <... for leading self-awareness topics". (EP 2).

The participants of the research note that various on-line means are much more attractive for pupils; the career specialists miss them. The lack of interactive means showed up: "the most of the work with those pupils is on the internet as they care for this, it drives them and is interesting. All the rest, the paper versions, are boring since long time ago. $<\ldots>$ the internet, as the films are somehow static, but game-type, interactive, so they themselves might go somehow through levels. Then they get involved indeed." (E V1); "tests, especially the paper ones, are slightly out-of-date. Give them the same test on paper and in a computer, and everybody will gladly do the computerised one. They like ticking and getting the result immediately. And the paper ones, they $<\ldots>$ do not want." (D 2)). The research disclosed the challenge related with the lack of tests on subjects of the career, designated for pupils, which could be applied by both, the career specialists with psychological education (" $<\ldots>$ Namely, $<\ldots>$, there is $a$ shortage of $<\ldots>$ tests, questionnaires in Lithuanian) $<\ldots>$ valid, normal. One can go to the internet and find self-awareness, but I always say that this is a game. $<\ldots>$ but, factually, there is no many tools for those who work, and not very good ones... " $(R 1)$ ), and those without it ("new tests which might be used." (E M1). "And not only for the use by a psychologist, but also by career specialists." ( $E V$ 1). The participants of the research also emphasized the necessity of video material designated for provision of career services ("when I lead class meetings I cannot go there and just beat about the bush there. I must have visual material. Everybody is already sick and tired of slides; they are good maybe just for me, to remind what to speak about, but for the kids there must be breaks with visual material. <...> But that does not mean that the film shall last 45 minutes. $5 \mathrm{~min}$ or $7 \mathrm{~min}$ is enough. Then you can make your lesson diversified. (L1)). The challenge of absence of a database has also been distinguished. The participants of the research noted that there was a serious lack of a general, continuously 
Merfeldaite et al., 2020. Challenges for Education Career in the Lithuanian Schools of General Education: Experience of Career Specialists

supported, informational database, which would contain all available informational, counselling, methodological material for career specialists. ("This issue should be for all individuals working with career issues, available matters, well, somewhere <...> in some bank." (L1); "and, in order not to die with some project, which becomes incapable face." (GV1); <...> it is very convenient $<\ldots>$ when there is some platform containing everything." (A2); "<... pages. Links to everything in one place. This is what is missing very much." (L1)).

The research disclosed that the challenges in the activity of career specialists at general education schools also relate to the process of qualification (self-) improvement and its needs. The challenges relates to both, the variety of qualification (self-) improvement forms and the content of (self-) improvement of qualification. According to the participants of the research, one of the most required forms of qualification (self-) improvement are trainings, seminars based on experience sharing ("more often, just maybe once or twice a year to make such a meeting of career specialists, and a round table, and discussions, and conversations, and sharing of information." (E1); "the gathering of career specialists, and demonstration that active people are still present, that you are not alone there. It gives some kind of inspiration." (A2); "it is very nice to meet specialists from other schools, because one gets some new information, new contacts, or learn something that one does not maybe know deeply involved in one's work without seeing what is going on around." (D2); "I believe it would be purposeful to organise regular discussions, sharing of the newest professional experiences, the best practices and etc., meetings of career consultants from education institutions of a city/ a region." (R2)). The participants of the research emphasize that such qualification (self-) improvement events could be based not only on sharing of experiences on the national level, but in the international context as well: "I will carry the expectation of an international event $<\ldots>$ international experience, $<\ldots>$ work experience, $a$ conference or $<\ldots>$ a week with a Lithuanian group, groups from other countries and one is sharing, listening, what is good for them and one may take over something. Anyhow, this culture is better in other countries than in our country, and from time to time it would be fun to see and get some good experience." ( $G$ V 1);" As a matter of fact, yesterday, of all reports I liked, <...> namely, the Americans experienced all this themselves, the person demonstrated how it would be possible to work with pupils. <...>." (J 1)

As one of the events of qualification improvement, based on experience sharing, the participants distinguish case study groups: "<... case study groups, when we would come from different schools and different fields. Now I think that maybe we used to gather once a week and we all used to discuss the difficulties, the activities performed" (D 2). 
Career specialists miss advisory events designated for them: "If there were some place where people could get advice, those who know nothing, how to start, where to apply, what to do precisely, namely, what are the duties, the responsibilities, when one is a total freshman." (D2); "inviting a certain specialist who could lead training $<\ldots>$ and the specialist would take the responsibility to cooperate and to help answering all questions $<\ldots>$ he or she would be a kind of consultant, <... >." (A 2). It should be noted that the need for advisory events has been especially actualised during the discussion of the freshmen career specialists.

In the discussion of the focus group of the experienced career specialists the qualification (self-)improvement events based on experience training were emphasized: "Only experience-based" (G1); "<...> one very quickly takes over what one tries himself, what one does $<\ldots>$ the experience-based methods are the best" (J1).

The research disclosed that, when speaking about the variety of the content of the qualification (self-) improvement events, the informants, first of all, note the demand for training about the future professions and the prospects of the labour market: " $<\ldots>$ about general understanding of what is going on in the modern context." (A2); "more seminars on qualification improvement $<\ldots .>$ about the trends on the labour market, about the specialists, professions to be needed in the future."(E P2).

The research disclosed that career specialists see the necessity of qualification (self-) improvement events on integration of development of career competences into the school subject ("<... I had a chance to see a couple of events like that, so I understood that people do not understand quite well what it means. What did they do and what it means "to integrate", $<\ldots>$ so that the training is useful $<\ldots>$ how to integrate, what should be reflected there, how to relate those subjects." (D 2)). The participants of the research spoke about the demand for events on improvement of foreign languages ("my weak point is English, I am not afraid to admit it. $<\ldots>$ make an intensive course and definitely a number of teachers will come <...> (G V1); "one can take a lot if one knows it [the English language]. So to say, you remember. I do not know, I studied English, but also forgot it." (E V 1).).

The participants of the research emphasized the events on qualification (self-) improvement regarding provision of career services for the children with special needs and for their parents, and the absence of it ("<...> I never heard about any training designated for such children [with special needs]. And, specifically, what I am facing, even from classes of general education, the parents have many concerns, they say, that they have a program applied, where will they admit us further, what we shall do and how."(D 2)). The Law on Education (2011) obliges to pay exclusive attention to education of pupils with special needs. It is 
Merfeldaite et al., 2020. Challenges for Education Career in the Lithuanian Schools of General Education: Experience of Career Specialists

stated there that the special education needs are the needs for assistance and services in the process of education, occurring due to exceptional skills of an individual, inborn or acquired disorders, unfavourable factors of the surroundings. Therefore schools pay an important role: to assist a pupil with special education needs in combining his/her ambitions with the possibilities, and to help to move from one step of education to the next one. Scientists state that for a pupil with special education needs easy, quick enough socialisation, sensation of the community meaning is high importance (Survutaite, 2012), and the need to disclose one's skills and abilities is important for every person, including those having the most limitations of their activity (Galkiene, 2005).

\section{Conclusions}

The key problems faced by the career specialists providing career services at schools of general education associate with a heavy workload, the procedure for payment for the work, the lack of cooperation among the career specialists and of involvement of community into provision of career services.

In the opinion of the career specialists, there is a lack of informational and methodological means which would correspond to the special needs of the pupils, their age groups, the sizes of the groups. The variety of means by individual subjects is also poor. There is a lack of measures for development of knowledge of career possibilities and of the competences for integration on the labour market, as well as for self-awareness.

Career specialists working in general education schools actualize the following needs: an information database containing all available informational, counselling, methodological material designated for the career specialist is required; psychological tests on the subjects of self-awareness and career which could be applied by career specialists themselves, without having psychological education; attractive, corresponding to the needs of modern labour market and of the students, video material designated for career education.

For improvement of qualification of the career specialists of general education schools, experience-based training, and counselling events are requested. The demand for counselling events is expressed by the freshmen, and the need for experience-based training comes from the experienced career specialists. The main qualification improvement subjects associate with the analysis of future profession and the labour market, with provision of career services for the children with special needs and for their parents. The need for improvement of the foreign language has also been expressed. 


\section{References}

Career Guidance. A Handbook For Policy Makers. (2004). OECD.

Dèl Valstybės pažangos strategijos „Lietuvos pažangos strategija „Lietuva 2030” patvirtinimo. (2013). Lietuvos Respublikos Seimo nutarimas 20120515 Nr. XI-2015. Valstybès žinios, 61.

Denzin, N.K., \& Lincoln, Y.S. (1994). Handbook of qualitative research. Sage publications.

Flick, U. (2014). An introduction to qualitative research. Sage.

Galkienè, A. (2005). Heterogeniniu grupiu didaktika: specialieji poreikiai bendrojo lavinimo mokykloje. Šiauliai: Šiaulių universiteto leidykla.

Garnienè, D. (2006). Model of career education at general education school: Parameters and realisation principles. Summary of doctoral dissertation. Kaunas: Vytauto Didžiojo universiteto leidykla.

Howard, K.A.S., Carlstrom, A.H., Katz, A.D., Chew, A.Y., Ray, G.C., Laine, L., \& Caulum, D. (2011). Career aspirations of youth: Untangling race/ethnicity, SES, and gender. Journal of Vocational Behaviour, 79, 98-109.

Hughes, D., Mann, A., Barnes, S.A., Baldauf, B., \& McKeown, R. (2016). Careers education: International literature review. Warwik Institute for Employment Research. Retrieved from http://www.educationandemployers.org/wp-content/uploads/2016/07/Careersreview.pdf

Kalinauskaitė, R., Adaškevičienè, V., Tarnauskas, K., \& Žvirdauskas, D. (2005). Pasirinktu studiju ir mokykloje pasirinkto ugdymo turinio derme: Mokslinio tyrimo ataskaita. Kaunas: Vytauto Didžiojo universitetas.

Kattenbach, R., Lucke, J., Schlese, M., \& Schramm, F. (2011). Same but Different - Changing Career Expectations in Germany? Zeitschrift für Personalforschung, 25(4), 292-312.

Lietuvos Respublikos švietimo ir mokslo ministro 2014 m. sausio 15 d. ịsakymas Nr. V-72 Dèl Ugdymo karjerai programos patvirtinimo. TAR, 2014, Nr. 2014-04888.

LR Švietimo įstatymas. (1991, 2011, 2017). Valstybès žinios, 2011, 38-1804.

Meijers, F., Kuijpers, M., \& Gundy, C. (2013). The relationship between career competencies, career identity, motivation and quality of choice. International Journal for Educational and Vocational Guidance, 13(1), 47-66.

Navickienè, L. (2012). Karjeros konsultanto kvalifikacijos parametrai. Karjeros projektavimas: tyrimai ir konsultavimas. Retrieved from http://skktg.vdu.lt/downloads/zurnalas_karjera/ Navickiene_4.pdf

Nusche, D. (2008). Assessment of learning outcomes in higher education: a comparative review of selected practices: OECD Education Working Paper. 15, 29-Feb-2008. Retrieved from http://www.oecd.org/dataoecd/13/25/40256023.pdf

Patton, M.Q. (2005). Qualitative research, 3, 1633-1636. In Brian S. Everitt \& David Howell (Eds.), Encyclopedia of statistics in behavioral science. John Wiley \& Sons, Ltd, Chichester. Downloaded from https://vdocuments.mx/encyclopedia-of-statistics-inbehavioral-science-qualitative-research.html.

Pukelis, K. (2012). Karjeros projektavimas: kodèl ir kas? Karjeros projektavimas: tyrimai ir konsultavimas, 1, 12-45.

Pukelis, K., \& Katsarov, J. (2014). Karjeros paslaugų teikèjų akademinio rengimo modelio projektavimas Europoje. Karjeros projektavimas: tyrimai ir konsultavimas, 3, 10-36. Retrieved from https://www.mpcentras.lt/wp-content/uploads/2015/10/KARJEROSPROJEKTAVIMAS_3.pdf 
Merfeldaite et al., 2020. Challenges for Education Career in the Lithuanian Schools of General Education: Experience of Career Specialists

Railienè, A. (2007). Mokinių požiūris ì profesinio informavimo organizavimą bendrojo lavinimo mokykloje. Pedagogika: mokslo darbai, 88, 50-57.

Ramanauskaitè, A., Laužackas, R., Targamadzè, V., Indrašienė, V., Statauskienè, L., \& Bukantaitè, D. (2004). 14-19 metu paaugliu, linkusiu i praktine veikla, mokymosi krypties pasirinkimo galimybès: Tyrimo ataskaita. Retrieved from www.smm.lt/svietimo_bukle/ docs/Ataskaita_baig.doc

Rogers, M., \& Creed, P. (2000). School-To-Work Transition: From Theory to Practice. Retrieved from http://adapt.it/adapt-indice-a-z/wp-content/uploads/2014/04/STWT_ Theory_Practice.pdf

Schuette, C.T., Ponton, M.K., \& Charlton, M.L. (2012). Middle school children's career aspirations: relationship to adult occupations and gender. The Career Development Quarterly, 60, 36-46.

Sinclair, S., Carlsson, R., \& Björklund, F. (2014). The role of friends in career compromise: Same-gender friendship intensifies gender differences in educational choice. Journal of Vocational Behavior, 84(2), 109-118.

Survutaite, D. (2012). Mokiniu, turinčiu specialiuju poreikiu, ikiprofesinio ugdymo raida Lietuvoje. Vilnius: Edukologija.

Thompson, M.N., \& Dahling, J.J. (2010). Image theory and career aspirations: Indirect and interactive effects of status-related variables. Journal of Vocational Behavior, 77, 21-29.

Ustinavičiūtè, L., Katkonienè, A., \& Žemaityte, I. (2011). Veiksniai, susiję su sėkmingu karjeros planavimu ir profesijos pasirinkimu paauglystejje. Socialinis darbas, 10(2), 196-180.

Valstybinè švietimo 2013-2022 metų strategija. (2013). Valstybės žinios, 140-7095.

Vrasmas, E., \& Vrasmas, T. (2012). Transition from school to work at young people with disabilities. Procedia - Social and Behavioral Sciences, 33, 433 - 437. Retrieved from https://www.sciencedirect.com/science/article/pii/S1877042812001668 